\title{
Wood density traits in Norway spruce understorey: effects of growth rate and birch shelterwood density
}

\author{
Göran Bergqvist \\ SLU, Department of Silviculture, 90183 Umeå, Sweden
}

(Received 4 June 1997; accepted 27 April 1998)

\begin{abstract}
Effects of growth rate and birch shelterwood density $\left(0,300\right.$ and 600 trees ha $\left.{ }^{-1}\right)$ on wood density traits in Norway spruce (Picea abies (L.) Karst.) understorey were evaluated for a trial in the boreal coniferous forest 56 years after establishment of the stand and 19 years after establishment of the trial. Wood density traits were measured by micro-densitometry for annual rings 21-30 extracted at breast height. In addition, ring width and mean density were measured for all annual rings. Growth rate was generally low with a mean ring width of $1.3 \mathrm{~mm}$. Radial variations in ring width and density depended more on calendar ycar than on cambial age. The shelterwoods had moderate d fluctuations in ring width, but not in wood density. For annual rings $21-30$, the mean density was $12 \%$ higher in trees of the lowest growth rate compared to trees of the highest growth rate. Also, minimum density and latewood percentage were higher in trees with the lowest growth rate compared to all other trees, while there were no significant effects due to shelterwood treatment for any of the wood density traits tested. An increase in ring width from 1 to $2 \mathrm{~mm}$ resulted in an $18 \%$ decrease in wood density. Latewood percentage explained $84 \%$ of the variation in wood density. (@ Inra /Elsevier, Paris.)
\end{abstract}

Norway spruce understorey / birch shelterwood / wood density / growth suppression / latewood percentage

Résumé - Caractéristiques de la densité du peuplement dans le sous-étage de sapin de Norvège : effets du taux de croissance et de la densité du peuplement de bouleaux résultant de la régénération par coupes progressives. Les effets du taux de croissance et de la densité du peuplement de bouleau résultant de la régénération par coupe progressive $\left(0,300\right.$ et 600 arbres ha $\left.^{-1}\right)$ sur les caractéristiques de la densité du peuplement de sapin de Norvège (Picea abies (L.) Karst.) sont évalués pour un essai dans la forêt de conifères boréale 56 ans après l'établissement du peuplement forestier et 19 ans après la mise en place de l'essai. Les caractéristiques de la densité forestière sont mesurées par microdensitométrie pour les anneaux annuels 21-30 extraits à hauteur de poitrine. En outre, la largeur et la densité moyenne des anneaux sont mesurées pour tous les anneaux annuels. On note un taux de croissance généralement faible, avec une largeur moyenne des anneaux de $1,3 \mathrm{~mm}$. Il apparaît que les variations radiales de la largeur et de la densité des anneaux dépendent plus de l'année que de l'âge cambial. Les peuplements résultant de la régénération par coupes progressives présentent des fluctuations modérées dans la largeur des anneaux mais pas dans la densité. Pour les anneaux

E-mail: goran.bergqvist@ ssko.slu.se 
annuels 21-30, la densité moyenne est supérieure de $12 \%$ pour les arbres ayant le taux de croissance le plus faible par rapport aux arbres dont le taux de croissance est le plus élevé. D'autre part, la densité minimale et le pourcentage de bois d'automne sont plus élevés pour les arbres dont le taux de croissance est le plus faible par rapport à tous les autres arbres, tandis que l'on ne constate aucun effet significatif résultant du mode de régénération par coupes progressives pour aucune des caractéristiques de la densité du peuplement étudiées. On note qu'une augmentation de la largeur des anneaux de 1 à $2 \mathrm{~mm}$ se traduit par une baisse de $18 \%$ de la densité du peuplement. Le pourcentage de bois d'automne explique $84 \%$ de la variation dans la densité du peuplement. (@ Inra /Elsevier, Paris.)

sous-étage de sapin de Norvège / peuplement de bouleaux résultant de la régénération par coupes progressives / densité du peuplement / ralentissement de croissance / pourcentage de bois d'automne

\section{INTRODUCTION}

Several theories have been suggested regarding the influence of crown development on wood properties including mechanical, nutritional, water conductance and hormonal regulation, as reviewed by Lindström [28]. Silvicultural treatments that affect competition and crown development can thus be expected to affect wood properties [7]. Wood density is considered a key property, affecting for example pulp yield per unit of wood volume [54]. A high and uniform wood density is desirable for most products [41]. Generally, a negative correlation between annual ring width and wood density has been demonstrated for Norway spruce (Picea abies (L.) Karst.), suggesting that a low growth rate promotes the production of high-density wood [22, 40]. However, wood density also shows large variations within and between trees of the same species growing at similar rates [54].

Norway spruce is considered to be a semi-shade tolerant species and can adapt to a wide variety of light conditions. Stratified stand mixtures, composed of shade tolerant late successional species in the lower strata and light demanding early successional species in the upper strata, have been recommended as a means of gaining a higher volume yield compared to a monoculture [3]. Norway spruce growing under a birch (Betula spp.) shelter is a common type of two-storied stand in the Scandinavian boreal forest [16].
Shelterwood systems are used in forestry worldwide mainly for regeneration purposes, and today this silvicultural method is the focus of increasing interest. Compared to conditions on a clear-cut area, a shelter will affect the availability of nutrients and water [16], temperature $[13,39,43,44]$ and wind speed [38] as well as quantity and quality of light [32] for the understorey trees. This in turn will affect their growth rate and crown development $[12,33,50]$. In frostprone areas, the use of shelterwoods is of special interest as a means of raising the minimum temperature and reducing excess light, thereby reducing frost damage to the understorey trees [2, 30, 42].

A high wood density for spruce growing under shelter might be expected if, for instance, low spring temperatures under shelter results in a delayed spring flushing, since trees with early flushing show lower wood density compared to late flushing trees [25]. On the other hand, wood density is also positively correlated with light intensity when compared at the same ring width $[10,35]$. Since a shelterwood will reduce light intensity for the understorey trees, this might also result in lower wood density for the understorey trees.

The objective of this investigation was to evaluate the effects of growth rate and birch shelterwood density on wood density traits for Norway spruce understorey in a trial in the boreal coniferous forest. Radial fluctuations in ring width and mean density 
from pith to bark, juvenile wood distribution and wood density traits (i.e. mean, minimum and maximum density, ring width, uniformity factor and latewood percentage) in annual rings 21-30 from the pith were examined by micro-densitometry on radial increment cores taken at breast height.

\section{MATERIALS AND METHODS}

\subsection{Stand and trial description}

The site is located in the province of Västerbotten, Sweden $\left(64^{\circ} 18^{\prime} 30^{\prime \prime} \mathrm{N}, 19^{\circ} 44^{\prime} 55^{\prime \prime} \mathrm{E}\right.$, altitude $260 \mathrm{~m}$ ) within the middle boreal forest zone [1]. Temperature sum $\left(T S_{5}\right)$, i.e. the summation of all daily mean temperature values exceeding $+5^{\circ} \mathrm{C}$ is 828 degree days and the growing season averages 146 days according to Morén and Perttu [34]. The soil is till, sand-silt, and the field vegetation is dominated by $\mathrm{VaC}$ cinium myrtillus L., indicating site index G18, i.e. an 18 -m dominant height of Norway spruce at 100 years of age [14].

Following clear-felling and prescribed burning in 1930, the stand was regenerated by direct seeding of Norway spruce (Picea abies (L.) Karst.) and Scots pine (Pinus sylvestris L.) in 1938, using seeds of local provenance. The Norway spruce seedlings were soon overgrown by downy birch (Betula pubescens Ehrh.) and silver birch (Betula pendula Roth) suckers, and pre-commercial thinning among the birch suckers was performed in 1951. The field trial was established in 1973 and 1975. At the time of trial establishment, the number of birch and the few remaining Scots pine overstorey trees amounted on average to $2000 \mathrm{ha}^{-1}$. The average height was $13 \mathrm{~m}$. The average diameter at breast height (DBH; $1.3 \mathrm{~m}$ ) over bark (o.b.) and average standing wood volume were $11-12 \mathrm{~cm}$ and $130 \mathrm{~m}^{3}$ $\mathrm{ha}^{-1}$, respectively, while the Norway spruce understorey totalled approximately 3000 trees $\mathrm{ha}^{-1}$ with a mean DBH o.b. of $3-5 \mathrm{~cm}$, an average height of 2-4 $\mathrm{m}$ and an average standing wood volume of $8-10 \mathrm{~m}^{3} \mathrm{ha}^{-1}$. The following shelterwood densities were established: 1 ) dense shelterwood, 600 trees ha-1; 2) sparse shelterwood, 300 trees ha $\mathrm{a}^{-1}$; and 3 ) no shelterwood. The shelterwoods consisted of silver birch and Scots pine, constituting 96 and $4 \%$ of the total wood volume, respectively. Allotment of shelterwood treatments to plots was randomized.
Removal of overstorey trees was performed during 1973, when four replications of each of the dense and no shelterwood treatments were established, and during 1975 when two replications were established for the sparse shelterwood treatment. All replications were 0.1 ha in size. Removal of excess Norway spruce stems took place in 1975 for all treatments and replications, leaving 1500 trees $^{-1}$ with an average DBH o.b. of approximately $3.5 \mathrm{~cm}$, an average height of $3.5 \mathrm{~m}$ and an average standing wood volume of $6 \mathrm{~m}^{3} \mathrm{ha}^{-1}$.

Two replications each of the dense shelterwood and no shelterwood treatments were randomly selected for this investigation, while both replications were included for the sparse shelterwood treatment. Wood sampling took place in October 1994, 19 growing seasons after trial establishment. At the time of sampling, the Norway spruce understorey trees were approximately $8-9 \mathrm{~m}$ tall, while the height of the shelterwood trees was $18-19 \mathrm{~m}$ (see table I).

\subsection{Selection of sample trees and wood sampling}

Prior to sampling, all Norway spruce trees in each shelterwood treatment were divided into three growth rate classes based on DBH o.b.: 1) high growth rate, over $11 \mathrm{~cm} \mathrm{DBH} \mathrm{o.b.;} \mathrm{2)} \mathrm{inter-}$ mediate growth rate, $8-11 \mathrm{~cm} \mathrm{DBH} \mathrm{o.b.;} \mathrm{and} \mathrm{3)}$ low growth rate, under $8 \mathrm{~cm} \mathrm{DBH} \mathrm{o.b.} \mathrm{A} \mathrm{total}$ of 90 trees, i.e. ten from each growth rate class within each shelterwood treatment were randomly selected. The sample trees surpassed actual mean DBH o.b. for the dense and sparse shelterwood by approximately $10 \%$ (table II). From each selected tree, an increment core of $4.5 \mathrm{~mm}$ diameter was extracted from bark to pith at breast height, from a randomly selected compass direction. Branches were avoided.

\subsection{Measurements}

Wood density variations were measured on $1-\mathrm{mm}$ thick samples prepared from the increment cores using a direct scanning micro-densitometer with automatic angle alignment and a resolution of $0.02 \mathrm{~mm}$. Measurement precision was estimated to $\pm 5 \%$. Wood density was measured at $5.0 \pm 0.62 \%$ (mean $\pm \mathrm{SD}$ ) moisture content and normalized to oven-dry density. Samples were not extracted before measurement. Methods of sample preparation, measurement 
Table I. Stand characteristics for the different shelterwood treatments at the time of sampling. Arithmetic averages for two replications per treatment.

\begin{tabular}{|c|c|c|c|c|}
\hline & $\begin{array}{l}\text { No. of } \\
\text { trees } \\
\left(\text { ha }^{-1}\right)\end{array}$ & $\begin{array}{l}\text { Diameter } \\
\text { o.b. }^{\text {a }} \\
(\mathrm{cm})\end{array}$ & $\begin{array}{l}\text { Average } \\
\text { height }^{\mathrm{b}} \\
(\mathrm{m})\end{array}$ & $\begin{array}{c}\text { Wood } \\
\text { volume } \\
\left(\mathrm{m}^{3} \mathrm{ha}^{-1}\right)\end{array}$ \\
\hline \multicolumn{5}{|c|}{ Norway spruce understorey } \\
\hline $\begin{array}{l}\text { Dense shelterwood } \\
\text { Sparse shelterwood } \\
\text { Number of shelterwood }\end{array}$ & $\begin{array}{l}1515 \\
1495 \\
1485\end{array}$ & $\begin{array}{l}8.6 \\
8.6 \\
9.8\end{array}$ & $\begin{array}{l}8.8 \\
8.2 \\
8.6\end{array}$ & $\begin{array}{l}43.0 \\
39.8 \\
53.9\end{array}$ \\
\hline \multicolumn{5}{|l|}{ Birch shelterwood } \\
\hline $\begin{array}{l}\text { Dense shelterwood } \\
\text { Sparse shelterwood }\end{array}$ & $\begin{array}{l}585 \\
300\end{array}$ & $\begin{array}{l}18.8 \\
20.8\end{array}$ & $\begin{array}{l}18.1 \\
18.6\end{array}$ & $\begin{array}{l}132.6 \\
76.0\end{array}$ \\
\hline
\end{tabular}

${ }^{a}$ Diameter corresponding to mean basal area at breast height over bark $\left(\sqrt{ } \sum d^{2} / n\right) ;{ }^{\mathrm{b}}\left(\sum d^{2} h / \Sigma d^{2}\right) ;{ }^{\text {c }}$ from stump to tip, calculated according to Brandel [6].

Table II. Arithmetic mean diameter $(\mathrm{cm})$ at breast height $\mathrm{o} . \mathrm{b}$. for the Norway spruce understorey at the time of sampling for the different shelterwood treatments and growth rate classes, for all trees and for sample trees. One SE of the mean is given within brackets.

\begin{tabular}{|c|c|c|c|c|}
\hline \multirow[b]{2}{*}{ Growth rate class } & \multicolumn{3}{|c|}{ Shelterwood } & \multirow[b]{2}{*}{ Average } \\
\hline & Dense & Sparse & No & \\
\hline \multicolumn{5}{|l|}{ All trees } \\
\hline High & $12.0(1.4)$ & $12.2(1.3)$ & $12.3(1.2)$ & $12.2(0.1)$ \\
\hline Intermediate & $9.4 \quad(0.7)$ & $9.2 \quad(0.7)$ & $9.4(0.7)$ & $9.4(0.1)$ \\
\hline Low & $6.6(0.9)$ & $6.3 \quad(1.1)$ & $6.9(1.1)$ & $6.6(0.1)$ \\
\hline Average & $8.6 \quad(0.1)$ & $8.6 \quad(0.1)$ & $9.8 \quad(0.1)$ & $9.0(0.1)$ \\
\hline \multicolumn{5}{|l|}{ Sample trees } \\
\hline High & $12.0 \quad(0.4)$ & $12.2 \quad(0.3)$ & $12.5(0.5)$ & $12.2(0.2)$ \\
\hline Intermediate & $9.3(0.2)$ & $9.4 \quad(0.3)$ & $9.3(0.2)$ & $9.3(0.1)$ \\
\hline Low & $7.1 \quad(0.2)$ & $6.9 \quad(0.3)$ & $7.0 \quad(0.2)$ & $7.0 \quad(0.1)$ \\
\hline Average & $9.4 \quad(0.4)$ & $9.6 \quad(0.4)$ & $9.6 \quad(0.5)$ & $9.5 \quad(0.2)$ \\
\hline
\end{tabular}

and normalization as well as the underlying theories and design of the equipment have been described in detail by Jonsson et al. [19], Larsson et al. [26] and Pernestål and Jonsson [45]. A total of 11 samples failed in the preparation process, leaving 79 scanned increment cores available for further analysis. The increment cores consisted of an average of 34 annual rings (table $11 I$ ); thus a total of more than 2600 individual annual rings were scanned. For further analysis, annual rings with cracks or reaction wood were disregarded. Also the annual rings formed during 1994, i.e. those closest to the bark, were excluded from further analysis due to difficulty in distinguishing between density readings from wood and cambial tissue.

\subsection{Calculations and statistical analysis}

Annual rings of cambial age 21 to 30 years were selected for the statistical evaluation of effects due to shelterwood treatment or growth 
Table III. Number of Norway spruce understorey trees in the sample and their arithmetic mean total age at breast height at the time of sampling, with one SE of the mean given within brackets for the different shelterwood treatments and growth rate classes.

\begin{tabular}{|c|c|c|c|c|}
\hline \multirow[b]{2}{*}{ Growth rate class } & \multicolumn{3}{|c|}{ Shelterwood } & \multirow{2}{*}{$\begin{array}{l}\text { Total/ } \\
\text { average }\end{array}$} \\
\hline & Dense & Sparse & No & \\
\hline \multicolumn{5}{|c|}{ No. of trees in sample } \\
\hline High & 10 & 10 & 9 & 29 \\
\hline Intermediate & 10 & 8 & 9 & 27 \\
\hline Low & 8 & 6 & 9 & 23 \\
\hline Total & 28 & 24 & 27 & 79 \\
\hline \multicolumn{5}{|c|}{ Total age at breast height (yr) } \\
\hline High & $35.5(1.1)$ & $38.4 \quad(0.6)$ & $36.8(0.8)$ & $36.9(0.5)$ \\
\hline Intermediate & $33.0 \quad(0.9)$ & $36.4 \quad(1.7)$ & $30.8(1.6)$ & $33.3(0.9)$ \\
\hline Low & $29,8 \quad(0.6)$ & $35.3(0.8)$ & $28.6(1.0)$ & $30.7 \quad(0.7)$ \\
\hline Average & $33.0 \quad(0.7)$ & $37.0 \quad(0.7)$ & $32.0 \quad(0.9)$ & $33.9(0.5)$ \\
\hline
\end{tabular}

rate class on wood density traits. This selection, rather than including all annual rings formed during the 19-year trial period, was performed in order to: 1) avoid comparing annual rings of different ages; 2 ) only include annual rings formed after the trial was established; and 3) only include mature wood. The following wood density traits were recorded or calculated; arithmetic mean ring width, arithmetic mean density, and minimum and maximum density. Latewood percentage was calculated as the percentage of all density values that exceeded $540 \mathrm{~kg} \mathrm{~m}^{-3}$, the estimated equivalent to Mork's index on an ovendry weight, oven-dry volume basis [15]. The uniformity factor, i.e. a measure of the variability in wood density, was calculated according to Olson and Arganbright [41]:

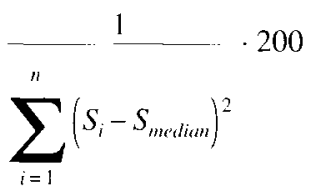

where $S_{i}$ are percentiles of the wood density values, $n$ is 20 , and $S_{\text {median }}$ is the overall median density value for the whole material, in this case $367 \mathrm{~kg} \mathrm{~m}^{-3}$.

One value for each density trait was calculated per tree; thus individual trees were used as observations in all statistical analyses. The average of 8.5 annual rings with an average cambial age of 25 years was included in the calculation of tree mean values (table $\mathrm{IV}$ ).
In addition, arithmetic mean wood density and arithmetic mean ring width were calculated for all annual rings from pith to bark separately in order to examine radial variations, and the coefficient of variation (CV) for density and ring width was calculated for each tree. An attempt was made to manually establish a juvenile-mature wood boundary, based on the definitions of juvenile and mature wood given by Rendle [46] (i.e. "characterized anatomically by a progressive increase in the dimensions and corresponding changes in the form, structure and disposition of the cells..." and "the cells in general having reached their maximum dimensions and the structural pattern being fully developed and more or less constant..." for juvenile and mature wood, respectively).

Data were tested for homoscedasticity. Differences in arithmetic mean ring width, arithmetic mean density, minimum and maximum density, uniformity factor and latewood percentage (for annual rings 2 $\mathrm{l}-30$ ) and $\mathrm{CV}$ for density and ring width (for all annual rings) due to shelterwood treatment or growth rate class were evaluated with two-way analysis of variance using the General Linear Model (GLM) procedure. The following model was applied:

$$
Y_{i j k}=\mu+\alpha_{i}+\beta_{j}+(\alpha \beta)_{i j}+\varepsilon_{i j k}
$$

where $\mu$ is the overall mean, $\alpha_{i}$ is shelterwood treatment, $\beta_{j}$ is growth rate class, $(\alpha \beta)_{i j}$ is the interaction term and $\varepsilon_{i j k}$ is the random error term. Both shelterwood treatment and growth rate class were regarded as fixed effects and type III sums 
Table IV. Characteristics of annual rings 21-30 at breast height included in the statistical analyses of wood density traits for the different shelterwood treatments and growth rate classes. Arithmetic mean values with one $\mathrm{SE}$ of the mean given within brackets.

\begin{tabular}{|c|c|c|c|c|}
\hline \multirow[b]{2}{*}{ Growth rate class } & \multicolumn{3}{|c|}{ Shelterwood } & \multirow[b]{2}{*}{ Average } \\
\hline & Dense & Sparse & No & \\
\hline \multicolumn{5}{|c|}{ No. of annual rings in analysis } \\
\hline $\begin{array}{l}\text { High } \\
\text { Intermediate } \\
\text { Low } \\
\text { Average }\end{array}$ & $\begin{array}{ll}9.2 & (0.4) \\
9.2 & (0.7) \\
7.5 & (0.5) \\
8.7 & (0.3)\end{array}$ & $\begin{array}{ll}9.4 & (0.4) \\
8.8 & (0.4) \\
8.5 & (0.8) \\
9.0 & (0.3)\end{array}$ & $\begin{array}{rr}10.0 & (0.0) \\
7.8 & (0.9) \\
6.1 & (1.0) \\
8.0 & (0.5)\end{array}$ & $\begin{array}{ll}9.5 & (0.2) \\
8.6 & (0.4) \\
7.2 & (0.5) \\
8.5 & (0.2)\end{array}$ \\
\hline \multicolumn{5}{|c|}{ Average cambial age of annual rings in analysis (year) } \\
\hline $\begin{array}{l}\text { High } \\
\text { Intermediate } \\
\text { Low } \\
\text { Average }\end{array}$ & $\begin{array}{ll}25.6 & (0.2) \\
25.2 & (0.4) \\
24.6 & (0.4) \\
25.2 & (0.2)\end{array}$ & $\begin{array}{ll}25.8 & (0.2) \\
25.8 & (0.3) \\
25.0 & (0.4) \\
25.6 & (0.2)\end{array}$ & $\begin{array}{ll}25.5 & (0.0) \\
24.5 & (0.5) \\
23.9 & (0.5) \\
24.6 & (0.2)\end{array}$ & $\begin{array}{ll}25.7 & (0.1) \\
25.1 & (0.2) \\
24.4 & (0.2) \\
25.1 & (0.1)\end{array}$ \\
\hline \multicolumn{5}{|c|}{ Average year of ring formation } \\
\hline $\begin{array}{l}\text { High } \\
\text { Intermediate } \\
\text { Low } \\
\text { Average }\end{array}$ & $\begin{array}{l}1984 \\
1986 \\
1989 \\
1986\end{array}$ & $\begin{array}{l}1981 \\
1983 \\
1983 \\
1983\end{array}$ & $\begin{array}{l}1983 \\
1988 \\
1989 \\
1987\end{array}$ & $\begin{array}{l}1983 \\
1986 \\
1988 \\
1985\end{array}$ \\
\hline
\end{tabular}

of squares were calculated. Differences were considered significant at $P \leq 0.05$. When significant effects of shelterwood treatment or growth rate class were found, a Tukey post-hoc test was performed.

Regression curves, relating mean wood density to mean ring width for annual rings $21-30$, were calculated using the density level regression developed by Olesen [40]:

$$
R=a+\frac{b}{(c+R W)}=a+b R W^{\prime}
$$

where $R$ is wood density, $R W$ is ring width, $R W^{\prime}$ is transformed ring width (this enables the use of linear regression) and $a, b$ and $c$ are positive constants. For constant $c$, the value of 2 was used in accordance with recommendations by Danborg [8]. Linear regression was also used to examine the relationship between mean wood density and latewood percentage for annual rings 21-30.

Regressions were calculated for each shelterwood treatment and each growth rate class separately, and differences were tested using dummy variables as described by Zar [53]. All analyses were performed using SPSS 7.0 for Windows [47].

\section{RESULTS}

Radial fluctuations in annual ring width and wood density were generally more affected by calendar year of ring formation than by cambial age (figure 1). No obvious systematic trends due to cambial age were apparent, and it was consequently not possible to establish a juvenile-mature wood boundary based on radial variations in annual ring width or wood density.

For spruce in the no shelterwood treatment, annual ring width increased abruptly by approximately $100 \%$ and for approximately 5 years in response to the total release from overstorey trees in 1973 (figure I). The coefficient of variation (CV) for annual ring width increased with decreasing shelterwood density and was $22.4 \pm 1.10,27.2 \pm 1.00$ and $36.7 \pm 2.17 \%$ (mean $\pm \mathrm{SE}$ ) for spruce in the dense, sparse and no shelterwood treatments, respectively. According to the ANOVA there was a strong significant effect of shelterwood treatment, but not growth rate class, 


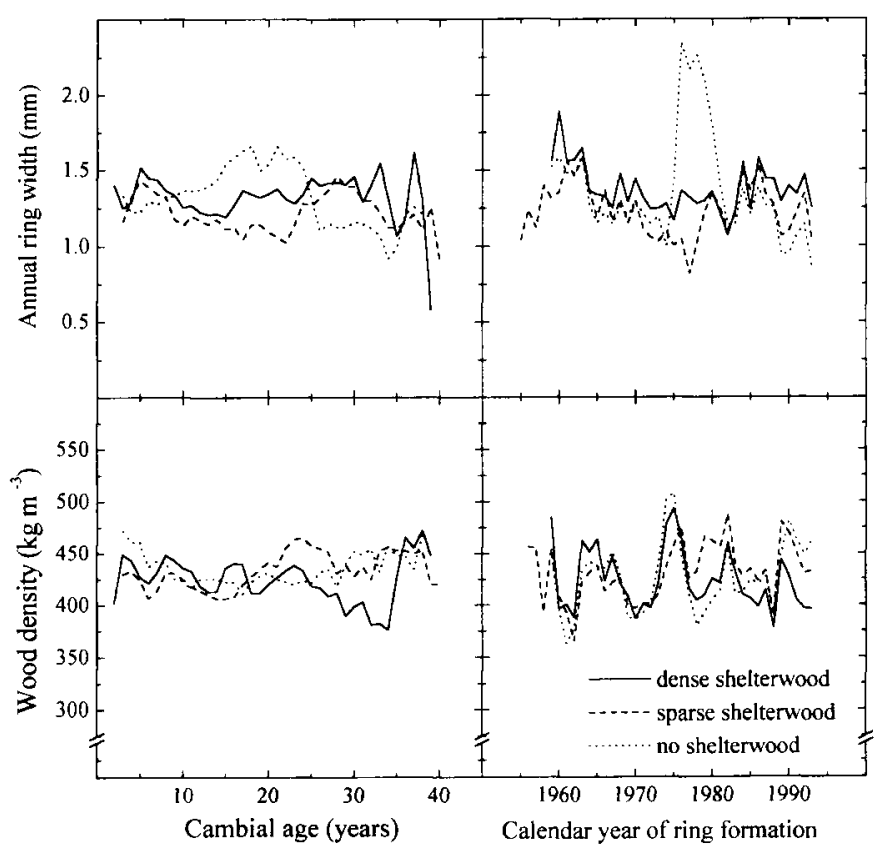

Figure 1. Radial variations in annual ring width (top) and wood density (bottom) at breast height for Norway spruce understorey in the different shelterwood treatments, due to cambial age (left) and calendar year of ring formation (right). Lines are based on the arithmetic average values of all trees in each treatment.

on CV for annual ring width (table $V$ ) with $\mathrm{CV}$ for Norway spruce in the no shelterwood treatment being significantly higher than that of the other treatments according to the Tukey test.

Radial fluctuations in wood density were generally smaller than fluctuations in ring width, and were not significantly affected by shelterwood density or growth rate class (table V). The $\mathrm{CV}$ was $13.6 \pm 0.52,11.3 \pm$ 0.62 and $12.5 \pm 0.83 \%$ (mean $\pm \mathrm{SE}$ ) for spruce in the dense, sparse and no shelterwood treatments, respectively.

According to the ANOVA, the shelterwood treatment had no significant effect on any of the wood density traits tested for annual rings $21-30$, while there was a strongly significant effect of growth rate class on all variables tested except for the maximum density and uniformity factor (table $V I$ ). Generally, a large proportion of the total sums
Table V. Effects of shelterwood treatment (S) and growth rate class $(\mathrm{G})$, individually and in combination on the coefficient of variation $(\mathrm{CV})$ for radial fluctuations in ring width and wood density for all annual rings at breast height, according to analysis of variance with sums of squares expressed as percent of total SS.

\begin{tabular}{lrrrr}
$\begin{array}{l}\text { Source of } \\
\text { variation }\end{array}$ & d.f. & $\%$ & $F$ & $P$ \\
\hline \multicolumn{5}{l}{ CV for annual } \\
ring & width $(\%)$ & & \\
$\mathrm{S}$ & 2 & 37.3 & 24.36 & 0.000 \\
$\mathrm{G}$ & 2 & 1.0 & 0.66 & 0.517 \\
$\mathrm{~S} \times \mathrm{G}$ & 4 & 6.7 & 2.20 & 0.078 \\
Error & 70 & 55.0 & & \\
Total & 78 & & & \\
$\mathrm{CV}$ for mean density $(\%)$ & & \\
$\mathrm{S}$ & 2 & 6.6 & 2.75 & 0.070 \\
$\mathrm{G}$ & 2 & 0.0 & 0.06 & 0.940 \\
$\mathrm{~S} \times \mathrm{G}$ & 4 & 6.0 & 1.25 & 0.299 \\
Error & 70 & 87.4 & & \\
Total & 78 & & & \\
\hline
\end{tabular}


of squares was attributed to the error term, suggesting a pronounced tree to tree variability in the wood density traits tested.

Table VI. Effects of shelterwood treatment (S) and growth rate class $(\mathrm{G})$, individually and in combination, on wood density traits in annual rings 21-30 at breast height, according to the ANOVA with sums of squares expressed as percent of total SS.

\begin{tabular}{llllll}
$\begin{array}{l}\text { Source of } \\
\text { variation }\end{array}$ & d.f. & $\%$ & $F$ & $P$ \\
\hline
\end{tabular}

Annual ring width ( $\mathrm{mm})$

$\begin{array}{lrrrr}\mathrm{S} & 2 & 2.0 & 1.22 & 0.301 \\ \mathrm{G} & 2 & 38.3 & 24.01 & 0.000 \\ \mathrm{~S} \times \mathrm{G} & 4 & 5.2 & 1.64 & 0.173 \\ \text { Error } & 70 & 54.5 & & \\ \text { Total } & 78 & & & \end{array}$

Mean density $\left(\mathrm{kg} \mathrm{m}^{-3}\right)$

$\begin{array}{lrrrr}\mathrm{S} & 2 & 3.5 & 1.53 & 0.224 \\ \mathrm{G} & 2 & 12.3 & 5.31 & 0.007 \\ \mathrm{~S} \times \mathrm{G} & 4 & 1.9 & 0.42 & 0.793 \\ \text { Error } & 70 & 82.3 & & \\ \text { Total } & 78 & & & \end{array}$

Minimum density $\left(\mathrm{kg} \mathrm{m}^{-3}\right)$

\begin{tabular}{|c|c|c|c|c|}
\hline S & 2 & 0.4 & 0.02 & 0.981 \\
\hline $\mathrm{G}$ & 2 & 14.8 & 6.66 & 0.002 \\
\hline $\mathrm{S} \times \mathrm{G}$ & 4 & 6.8 & 1.54 & 0.201 \\
\hline Error & 70 & 78.0 & & \\
\hline Total & 78 & & & \\
\hline \multicolumn{5}{|c|}{ Maximum density $\left(\mathrm{kg} \mathrm{m}^{-3}\right)$} \\
\hline$S$ & 2 & 1.6 & 0.60 & 0.552 \\
\hline $\mathrm{G}$ & 2 & 2.6 & 1.00 & 0.375 \\
\hline $\mathrm{S} \times \mathrm{G}$ & 4 & 3.3 & 0.63 & 0.644 \\
\hline Error & 70 & 92.5 & & \\
\hline Total & 78 & & & \\
\hline \multicolumn{5}{|c|}{ Uniformity factor } \\
\hline $\mathrm{S}$ & 2 & 0.4 & 0.15 & 0.858 \\
\hline G & 2 & 1.0 & 0.38 & 0.688 \\
\hline $\mathrm{S} \times \mathrm{G}$ & 4 & 3.1 & 0.57 & 0.686 \\
\hline Error & 70 & 95.5 & & \\
\hline Total & 78 & & & \\
\hline \multicolumn{5}{|c|}{ Latewood percent (\%) } \\
\hline$S$ & 2 & 3.2 & 1.30 & 0.279 \\
\hline $\mathrm{G}$ & 2 & 8.6 & 3.52 & 0.035 \\
\hline $\mathrm{S} \times \mathrm{G}$ & 4 & 2.4 & 0.33 & 0.858 \\
\hline Error & 70 & 85.8 & & \\
\hline Total & 78 & & & \\
\hline
\end{tabular}

The arithmetic mean ring width for annual rings $21-30$ was $58 \%$ greater for the fast growing trees compared to the slow growing trees (table VII). Differences were highly significant between all growth rate classes.

Mean wood density for annual rings 21-30 increased with decreasing growth rate, and was $12 \%$ higher for the slow growing trees compared to the fast growing trees (table VII). This was associated with a higher minimum wood density and higher latewood percentage for the slow growing trees. The maximum wood density decreased as the growth rate decreased, although the differences were not statistically significant. The smaller range of wood density values for the trees with the lowest growth rate was not reflected in the uniformity factor, which showed no consistent variation with growth rate. Instead, the uniformity factor increased with increasing shelterwood density, although not significantly (table VII).

When the effect of ring width on wood density was taken into account by calculating density level regressions, there were no significant differences between any of the shelterwood treatments or growth rate classes for annual rings 21-30 (data not shown). Therefore, a common density level regression was computed showing that an increase in annual ring width from 1 to 2 $\mathrm{mm}$ would result in an $18 \%$ decrease in wood density, i.e. from 463 to $392 \mathrm{~kg} \mathrm{~m}^{-3}$. A further increase in ring width from 2 to $3 \mathrm{~mm}$ causes an additional $12 \%$ decrease in wood density, i.e. from 392 to $350 \mathrm{~kg} \mathrm{~m}^{-3}$ (figure 2).

Latewood percentage showed a strong correlation with mean wood density for annual rings 21-30 and, in a linear regression, it explained $84 \%$ of the variation in wood density (figure 3). No significant differences were detected between the regressions for the different shelterwood treatments or growth rate classes (data not shown), and thus a common regression was computed which showed that an increase in 
Table VII. Arithmetic mean values for wood density traits in annual rings $21-30$ at breast height for the different shelterwood treatments and growth rate classes with one SE of the mean given within brackets.

\begin{tabular}{|c|c|c|c|c|c|c|c|c|}
\hline \multirow[b]{2}{*}{ Growth rate class } & \multicolumn{6}{|c|}{ Shelterwood } & \multirow{2}{*}{\multicolumn{2}{|c|}{ Average }} \\
\hline & \multicolumn{2}{|c|}{ Dense } & \multicolumn{2}{|c|}{ Sparse } & \multicolumn{2}{|c|}{ No } & & \\
\hline \multicolumn{9}{|c|}{ Annual ring width $(\mathrm{mm})$} \\
\hline High & 1.51 & $(0.1)$ & 1.56 & $(0.1)$ & 1.77 & $(0.2)$ & $1.61^{\mathrm{A}}$ & $(0.1)$ \\
\hline Intermediate & 1.47 & $(0.1)$ & 1.23 & $(0.1)$ & 1.23 & $(0.1)$ & $1.32 \mathrm{~B}$ & $(0.1)$ \\
\hline Low & 1.11 & $(0.1)$ & 0.91 & $(0.1)$ & 1.02 & $(0.1)$ & $1.02^{C}$ & $(0.1)$ \\
\hline Average & $1.38^{a}$ & $(0.1)$ & $1.29^{\mathrm{a}}$ & $(0.1)$ & 1.34 a & $(0.1)$ & 1.34 & $(0.1)$ \\
\hline \multicolumn{9}{|c|}{ Arithmetic mean density $\left(\mathrm{kg} \mathrm{m}^{-3}\right)$} \\
\hline High & 401 & (19.6) & 438 & (12.4) & 407 & $(19.4)$ & $416^{\mathrm{A}}$ & $(10.1)$ \\
\hline Intermediate & 420 & (14.2) & 464 & (24.8) & 431 & $(14.3)$ & $436^{A B}$ & (10.4) \\
\hline Low & 462 & $(33.3)$ & 465 & $(16.3)$ & 475 & $(12.3)$ & $468^{\mathrm{B}}$ & $(12.7)$ \\
\hline Average & 425 a & (13.2) & $453^{a}$ & $(10.4)$ & $437 a$ & $(10.3)$ & 438 & $(6.7)$ \\
\hline \multicolumn{9}{|c|}{ Minimum density $\left(\mathrm{kg} \mathrm{m}^{-3}\right)$} \\
\hline High & 165 & $(19.0)$ & 164 & $(13.5)$ & 117 & $(17.6)$ & $150^{\mathrm{A}}$ & $(10.2)$ \\
\hline Intermediate & 153 & $(23.1)$ & 158 & $(27$ & 179 & $(1$ & $163^{\mathrm{A}}$ & $(12.5)$ \\
\hline Low & 196 & $(23.5)$ & 202 & $(16.9)$ & 222 & $(14.0)$ & $208^{B}$ & $(10.6)$ \\
\hline Average & $170^{a}$ & $(12.6)$ & $171:$ & (11.6) & 173 & (12.1) & 171 & $(6.9)$ \\
\hline \multicolumn{9}{|c|}{ Maximum density $\left(\mathrm{kg} \mathrm{m}^{-3.3}\right)$} \\
\hline High & 1013 & $(50.4)$ & 987 & $(31.6)$ & 1044 & $(32.8)$ & $1014^{\mathrm{A}}$ & $(22.5)$ \\
\hline Intermediate & 988 & (23.3) & 1025 & $(54.7)$ & 1017 & $(80.4)$ & $1009^{\mathrm{A}}$ & $(31.3)$ \\
\hline Low & 1016 & $(61.4)$ & 898 & $(38.5)$ & 973 & $(33.4)$ & $968^{\mathrm{A}}$ & $(27.5)$ \\
\hline Average & $1005^{a}$ & $(25.5)$ & $977^{i 1}$ & $(25.5)$ & $1011^{a}$ & $(30.4)$ & 999 & $(15.7)$ \\
\hline \multicolumn{9}{|l|}{ Uniformity factor } \\
\hline High & 227 & $(29.6)$ & 200 & $(15.9)$ & 193 & $(18.0)$ & $207^{A}$ & $(12.7)$ \\
\hline Intermediate & 223 & $(15.2)$ & 218 & $(52.3)$ & 237 & $(32.6)$ & $226^{\mathrm{A}}$ & $(19.0)$ \\
\hline Low & 206 & $(32.6)$ & 248 & $(33.0)$ & 199 & (15.8) & $215^{A}$ & (15.4) \\
\hline Average & $220^{a}$ & $(14.6)$ & $218^{a}$ & $(19.8)$ & $210^{a}$ & $(13.5)$ & 216 & $(9.1)$ \\
\hline \multicolumn{9}{|c|}{ Latewood percent (\%) } \\
\hline High & 18.2 & $(1.80)$ & 22.7 & $(1.60)$ & 19.1 & $(1.81)$ & $20.0^{\mathrm{A}}$ & $(1.04)$ \\
\hline Intermediate & 19.0 & (1.41) & 23.0 & $(3.00)$ & 20.1 & $(2.28)$ & $20.5^{\mathrm{A}}$ & $(1.27)$ \\
\hline Low & 25.6 & $(4.16)$ & 25.2 & $(2.31)$ & 23.5 & (1.81) & $24.7^{\mathrm{B}}$ & (1.65) \\
\hline Average & $20.6^{\text {a }}$ & $(1.51)$ & 23.4 & $(1.29)$ & 20.9 a & $(1.16)$ & 21.6 & $(0.78)$ \\
\hline
\end{tabular}

Values followed by the same letter are not significantly different according to the Tukey test. Capital letters denote differences between growth rate classes, lower-case letters differences hetween shelterwood treatments.

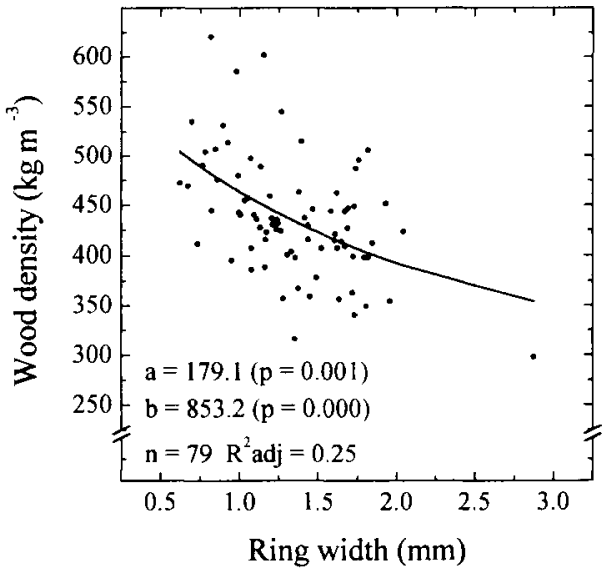

Figure 2. Density level at breast height for annual rings $21-30$ in the Norway spruce understorey and estimates for the regression $Y=a+b \cdot R W^{\prime}$, where $Y$ is wood density and $R W^{\prime}$ is transformed ring width.

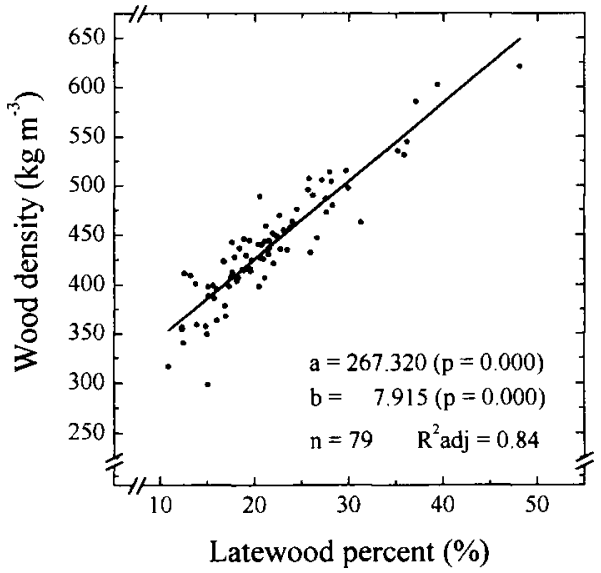

Figure 3. Regression of density on latewood percentage at breast height for annual rings $2 \mathrm{I}-30$ in the Norway spruce understorey and estimates for the regression $Y=a+b \cdot L W$, where $Y$ is wood density and $L W$ is latewood percentage. 
the proportion of latewood from 20 to $40 \%$ corresponded to an increase in wood density from 426 to $584 \mathrm{~kg} \mathrm{~m}^{-3}$, i.e. by $37 \%$.

\section{DISCUSSION}

Measuring wood density with micro-densitometry equipment usually generates large amounts of data. The normal way to present this data is to calculate mean values for individual annual rings, as in figure 1 . However, in statistical evaluation using ANOVA or regression, it is important to consider that values from individual annual rings within the same tree will most likely be correlated, and thus one of the basic restrictions on the data in such analyses will be violated [53]. Therefore, tree mean values were used as observations in all statistical evaluations. Based on the analysis of the residual plots, this model was deemed appropriate. Likewise, the juvenile-mature wood boundary could only be assessed manually rather than by statistical methods such as regression analysis, due to the risk of data being correlated.

Wood density was measured on samples without extraction, which might be important when comparing trees with different growth rates. Stairs et al. [49] reported a higher content of extractives in slow grown Norway spruce compared to fast grown trees. However, the amount of extractives is generally low in Norway spruce, i.e. below or around $2 \%[23,49]$; and Nylinder and Hägglund [37] found no significant correlation between content of extractives and wood density in Norway spruce.

A somewhat unexpected finding was the lack of a detectable juvenile wood zone irrespective of shelterwood treatment. Juvenile wood is produced in the inner annual rings closest to the pith, and exhibits pronounced systematical variations with increasing ring number for most wood properties [46]. Depending on the criteria for definition, the juvenile wood zone usually continues for 5 to 20 annual rings from the pith, and its rapid ring-to-ring variations will override any vari- ations due to, for instance, silvicultural treatment [4]. This was one reason for choosing annual rings of cambial age 21-30 years for the statistical evaluation. The failure to establish a juvenile-mature wood boundary was due to the absence of the characteristic density dip in juvenile wood (i.e. very high wood density closest to the pith followed by rapidly decreasing density for a number of annual rings, again followed by a rising density) that had been found in other investigations $[5,8,21,24,36]$. However, investigations on wood density in Norway spruce have normally studied widely-spaced trees growing on fertile sites in a relatively favourable climate, and thus they show fairly high growth rates. In an investigation of unevenly aged Norway spruce forests with suppressed juvenile growth showing a mean ring width of $1.64 \mathrm{~mm}$, Eikenes et al. [11] reported that it was not possible to separate juvenile and mature wood based on wood density or annual ring width. When examining wood properties in naturally regenerated Norway spruce growing on a fertile site but with severely suppressed juvenile growth due to an initial stand density of 76000 stems $\mathrm{ha}^{-1}$, Johansson [18] found no juvenile dip in the radial density variation. It could therefore be argued that the pronounced ring-to-ring variations generally used to define juvenile wood are only useful given trees with high juvenile growth rates. It is important to consider that all trees in this investigation were severely suppressed until establishment of the field trial in 1973-1975. At that time the trees averaged 10 years of age at breast height. The lack of a detectable juvenile wood zone, even in trees growing without shelter, is therefore considered to be mainly a result of the low overall growth rate which in turn might be due to the harsh climate, as demonstrated by the short growing season, low temperature sum and relatively low soil fertility and/or the suppressed growth for the first 10 years.

Mean wood density for annual rings 21-30 increased as growth rate decreased, and was highest for the slow growing trees. 
This pattern is supported by the findings of Johansson [17] and Mazet et al. [31]. With growth rate taken into account, there were no statistically significant differences in wood density in contrast to results reported by Kärkkäinen [20], who found that suppressed Norway spruce trees had a lower wood density and dominant trees a higher wood density than would have been predicted based on growth rate alone. The variation in wood density at a given ring width was very large between individual trees, resulting in a low $R^{2}$ for the regression. As argued by Ståhl and Karlmats [48], there is probably no causal relationship between ring width and wood density, but they are both related to annual weather conditions. This could explain why the pronounced increase in annual ring width for the Norway spruce after the release cutting in the no shelterwood treatment was not coupled to a similar decrease in wood density.

A lower growth rate resulted in an increased minimum wood density and decreased maximum wood density, although only changes in minimum density were statistically significant. Minimum density also increased with decreasing shelterwood density, although differences were small and not significant. The smaller range of wood density values for the trees with low growth rate was not accompanied by an increase in uniformity factor, so the two were apparently not correlated. Instead, the uniformity factor increased with increasing shelterwood density. Although not statistically significant, these results indicate that it might be possible to use shelterwoods as a means of producing a more homogeneous wood with respect to wood density.

Mean wood density in annual rings 21-30 was highest for trees growing under the sparse shelterwood and lowest for the trees growing under the dense shelterwood, although differences were small and not significant. This somewhat unexpected finding might be explained by the fact that, although of almost exactly the same cambial age, the annual rings included in the statistical analysis were formed during different years in the different shelterwood treatments.

Latewood percentage showed a pronounced influence on mean wood density for annual rings $21-30$, explaining $84 \%$ of the variation in density. This is in accordance with the findings of de Kort et al. [9], Lassen and Okkonen [27] and Lindström [29]. According to theories regarding hormonal regulation of wood formation, latewood is produced after apical growth cessation until the end of the growing season [52] and can be seen as an effect of the within-season growth rhythm, i.e. apical versus cambial growth. Wood density is negatively correlated with the dates of cambial growth initiation and latewood transition, and positively correlated with the date of cambial growth cessation [51]. However, the shelterwood densities compared in this investigation did not affect growth rhythm in the understorey trees; at least, the wood density traits tested did not reveal any such influence.

\section{CONCLUSIONS}

Considerable differences in wood density between trees with different growth rates were found, which gives the forester an argument for tree selection in the logging operation. If a residual stand with high mean wood density is desired, trees with high growth rates should be harvested early in thinning operations. On the other hand, if high wood density in the trees harvested during the thinning operation is more important, then trees with low growth rates should be harvested. The choice of silvicultural system, Norway spruce growing under shelter versus Norway spruce growing without shelter, seems to be less important than growth rate when managing stands for high wood density, at least for the shelterwood densities tested and at the low overall growth rates demonstrated in this investigation. It would be an exception if the shelterwood system resulted in a larger proportion of trees with 
low growth rates, something not considered in this investigation. However, when small fluctuations in annual ring width are desired, the shelterwood system provides an efficient tool of management. The results also indicate that Norway spruce growing under shelter produce a more homogeneous wood with regard to wood density, and that wood uniformity increases with increasing shelterwood density.

\section{ACKNOWLEDGEMENTS}

I thank B. Larsson for teaching us how to use the densitometry equipment, E. Jansson and R. Johansson for help in the field and in the laboratory, and S. Uvell for statistical advice. I am also grateful to U. Bergsten, B. Håncll, E.G. Stăhl, B. Elfving and K. Johansson for comments on the manuscript. Funding was provided by MoDo Skog and SLU, Faculty of Forestry, Graduate School in Wood and Fibre Science, Sweden.

\section{REFERENCES}

[1] Ahti T., Hämet-Ahti L.. Jalas J., Vegetation zones and their sections in northwestern Furope. Ann. Bol. Fenn. 5 (1968) 169-211.

[2] Andersson S.O., Treatment of young mixed stands with birch and conifers, in: Hägglund B., Peterson S. (Eds.), Broadleaves in Boreal Silviculture - An Obstacle or an Asset?, Swedish Univ. Agric. Sci., Dept. Silviculture, Umcå, Rep. 14, 1985, pp. 127-162.

13] Assman E., The Principles of Forest Yield Study, Pergamon Press, Oxford, 1970.

[4] Bendisen A., Properties ol wood from improved and intensively managed trees. For. Prod. J. (1978) $61-72$.

[5] Blouin D., Beaulicu J., Daoust G., Poliquin J., Wood quality of Norway spruce grown in plantations in Quebec, Wood Fiber Sci. 26:3 (1994) 342-353.

[6] Brandel G., Volume functions for individual trees, Scots pine (Pintus sy/lestris) Norway spruce (Picea abies) and birch (Betula pendula and Betula pubescens), Swedish Univ. Agric. Sci., Dept. For. Yield Res., Garpenberg, Rep. 26, 1990.

[7] Briggs D.G., Smith W.R., Effects of silvicul tural practices on wood properties of conifers: a review. in: Oliver C.D., Hanley D.P., Johnson J.A. (Eds.), Proceedings, Douglas Fir: Stand Management for the Future, Coll. For. Res., Univ. Washington, Seattle, 1986, Contrib. No. 55 .
[8] Danborg F., Density variations and the demarcation of the juvenile wood in Norway spruce, Danish For. Landscape Res. Inst., Res. Ser. 10, Lyngby, Denmark, 1994.

[9] de Kort I., Loeffen V., Baas P., Ring width, density and wood anatomy of Douglas fir with different crown vitality, IAWA Bull. (199!) 453-465.

[10] Denne M.P., Effects ol light intensity on tracheid dimensions in Picea sitchensis, Ann. Bot. 38 ( 1974 ) 337-345.

[11] Eikenes B., Kucera B.. Fjaertoft F., Storheim O.N., Vestol G.I.. Wood quality from uneven-aged forest, Res. Pap. Skogforsk 24, Ås, 1995 (in Norwegian with English summary).

[12] Greis I.. Kellomäki S., Crown structure and stem growth of Norway spruce undergrowth under varying shading. Silv. Fenn. 15:3 (1981) 306-322.

[13] Groot A.. Cartson D.W., Inthuence of shelter on night temperatures, frost damage, and bud break of white spruce seedlings, Can. J. For. Res. 26 (1996) $15.31-15.38$.

[14] Hägglund B., Lundmark J.E., Site index cstimations by means of site properties. Scots pine and Norway spruce in Swoden, Stud. For. Suec. 138 (1977) $1-33$.

| 15 | Heger L., Parker M.L., Kennedy R.W., X-ray densitometry: a technique and an example of applicaLion. Wood Sci. 7:2 (1974) 140-148.

[16] Jeansson E., Bergman F., Elfving B., Falck J., I undqvist L., Natural regeneration of pine and spruce, proposal for a research program, Swedish Univ. Agric. Sci. Dept. Silviculture, Umeả, Rep. 25, 1989.

[17] Johansson K., Influence of initial spacing and tree class on the basic density of Picea abies, Scand. J. For. Res. 8 (1993) 18-27.

[18] Johansson K., Effect of early competition on wood properties of Norway spruce, Doctoral thesis, Acta Univ. Agric. Suec., Silv. 19, SLU, Garpentherg, 1997.

[19] Jonsson B., Dissing E., Pernestål K., A high resolution and high speed annual ring analyser with automatic angle alignment, Swedish Univ. Agric. Sci, Dept. Biometry For. Manage., Umeå, Rep. 19, 1990.

[20] Kärkkäincn M., Effect of tree social status on basic density in Norway spruce, Silv. Fenn. 18:2 (1984) $115-120$.

[21] Kennedy R.W., Coniferous wood quality in the future: concerns and strategies, Wood Sei. Tech. 29 (1995) 321-338.

$122 \mid \mathrm{Klem}$ G.G.. Effect of planting space on the quality of spruce wood and sulphite pulp, Comm. Norw. For. Res. Inst.28 (1942) 257-293 (in Norwegian with English summary).

12.3| Klem G.G., The influcence of spacing on spruce quality, Comm. Norw. For. Res. Inst. 11 (1952) 47.3-506 (in Norwegian with English summary).

[24] Kyrkjecide P.A.. A wood quality study of suppressed, intermediate and dominant trees of plantation grown Picea abies, Diss. Skogsbrukskandidal degree, Agric. Univ. Norway, Ås, 1990. 
[25] Lacaze J.F., Polge H., Phenotypic relationship between wood density and growth critcria, late flushing, lamma shoots from young spruce seedlings, Ann. Sci. For. 273 (1970) 231-242 (in French with English summary).

[26] Larsson B., Pernestial K., Jonsson B., A wood sample preparation method for direcl scanning $X$-ray microdensitometry, Swedish Univ. Agric. Sci., Dept. For. Mensur. Manage., Umeå, Rep. 29, 1994.

[27] Lassen L.E.. Okkonen E.A.. Effect of rainfall and elevation on the specific gravity of coast Douglas fir, Wood Fiber Sci. 1 (1969) 227-235.

[28] Lindström H., Basic density in Norway spruce. Part I. A literature review, Wood Fiber Sci. 28:1 (1996) 15-27.

[29] Lindström $\mathrm{H}$., Fiher length, tracheid diameter and latewood percentage in Norway spruce: development from pith outwards. Wood Fiber Sci. 29:1 (1997) $21-34$.

[30] Lundmark T.. Photosynthetic responses to frost and excessive light in field-grown Scots pine and Norway spruce, Diss., SLU, Dept. Silviculture, Umeă. 1996.

[31] Mazet J.F., Nepveu G., Velling P.. Study of the effects of several environmental and silvicultural factors on the density of wood of Norway spruce (Piceed exelsa), silver fir (Abies alba) and Scots pine (Pinus sylvestris) of the north-eastern part of France, Stat. rech. qualité des bois. Inra 3, Champenoux. 1989 (in French with English summary).

[32] Messier C., Bellefleur P., Light quantity and quality on the forest floor of pioneer and climax stages in a birch-becch-sugar maple stand, Can. J. For. Res. 18 (1988) 615-622.

[33] Messier C., Puttonen P., Growth, allocation. and morphological responses of Betula pubescens and Betula pendula to shade in developing Scots pine stands, Can. J. For. Res. 25 (1995) 629-637.

[34] Morén A.S., Perttu K.L.. Regional temperitture and radiation indices and their adjustment to horizontal and inclined torest land. Stud. For. Suec.194. 1994.

|35] Nakugawa S., Inlluence of pruning and light intensity on the structure of annual rings of Todo fir (Abies sachalinensis Fr. Sehm. var. matriama Miyabe et Kudo), Bull. For. Prod. Res. Inst. Jpn 345 (1987) 81-100 (in Japanese with English summary).

[36] Norén A., Wood and pulp characteristics of juvenile Picec abies (L.) Karst. grown on agricultural and forest land. Swedish Univ. Agric. Sci., Dept. For. Yield Res., Garpenberg, Rep. 40, 1996.

[37] Nylinder P., Haggglund E., The influence of stiund and tree properties on yield and quality of sulphite pulp of Swedish spruce (Picea exelsci). Rep. For. Res. Inst. Sweden 44:11, 1954 (in Swedish with English summary).

1381 Odin H., Studies of wind and evaporation in forest stands and clear felled areas, R. Coll. Forestry.
Dept. Reforestation. Res. Notes 73, 1976 (in Swedish with English summary).

[39] Odin H., Magnusson B., Bäckström P.O., Effects of low shelterwood on temperature near the ground, in: Perttu K. (Ed.), Ecology and Management of Forest Biomass Production System, Swedish Univ. Agric. Sci., Dept. Ecol. Environ. Res. 15 (1984) pp. $77-99$.

[40] Olesen P.O., The interrelation between basic density and ring width of Norway spruce, Danish For. Res. Inst. 34 (1976) 341-359.

|41| Olson J.R., Arganbright D.C., The uniformity factor - a proposed method for expressing variations in specific gravity. Wood Fiber Sci. 9 (1977) 202-210.

142\} Örlander G., Shading reduces both visible and invisible frost damage to Norway spruce seedlings in the ficld. Forestry 66 (1993) 27-36.

[43| Ottosson-L_ölvenius M., Elfects of high pine shelterwoxd on temperature near the ground, in: Alexindersson H., Holmgren B. (Eds.). Climatological Extremes in the Mountain. Physiological Background, Geomorphological and Ecological Consequences, Uppsala Univ.. Dept. Phys. Geogr., Uppsala, UNGI Rep. 65 (1987) pp. $69-77$.

$|+4|$ Otosson-Löfvenius M.. Temperature and radiation regimes in pine shelterwood and clear-cut area, Diss., Swedish Univ. Agric. Sci., Dept. For. Ecol., Umeà. 1993.

|45] Pernestål K.. Jonsson B.. A method for automatic collimator alignment in microdensity measurements. Wood Sci. Tech. 30 (1996) 91-97.

[46| Rendle B.J., Juvenile and adult wood, J. Inst. Wood Sci. 5 (1960) 58-61.

[47] SPSS Inc.. SPSS Advanced Statistics 7.0 Updite. Chicago, 1996.

|48| Stahl E.G., Kirlmats U., Yield, wood properties, and timber harvest at establishment of seed-tree and shelterwood systems. Stud. For. Succ. 197. 1995.

149| Stairs G.R.. Marton R.. Brown A.F., Rizzio M., Petrik A.. Anatomical and pulping properties of fasi- and slow-grown Norway spruce, Tappi J. 49:7 (1966) 296-300.

|50| Taylor S.P.. Allaro R.I., DeL.ong C., Rankin L.. The effects of overstorey shading on white pine weevil damage to white spruce and its effects on spruce growth rates, Can. J. For. Res. 26 (1996) 306-312.

151) Vargas-Hernandez J., Adams W.T., Genetic relation hhips between wood density components and cambial growth rhythm in young coastal Douglas fir. Cinn. J. For. Res. 24 (1994) 1871-1876.

[52| Worrall J., Interrelationships among some phenological and wood property variables in Norway spruce. TAPPI J. 53:I (1970) 58-63.

[5.3] Zar J.H.. Biostatistical Analysis. 2nd edn, Prentice-Hall Inc., Englewood Cliffs. N.Y., 1984.

$1.54 \mid$ Zobel B.J., van Buijtenen J.P., Wood Variation. Its Causes and Control. Springer Verlig. Berlin, 1989. 